\title{
Counterfeit versus original patronage: Do emotional brand attachment, brand involvement, and past experience matter?
}

\author{
Xuemei Bian ${ }^{1} \cdot$ Sadia Haque ${ }^{1}$
}

Revised: 13 March 2019 / Published online: 19 March 2020

(c) The Author(s) 2020

\begin{abstract}
To enhance brand performance and to protect original brands from the unprecedented upsurge of counterfeits, marketers are continuously looking for effective anti-counterfeiting methods. Developing and maintaining emotional brand attachment and brand involvement with consumers have become a strategic marketing endeavor of luxury brands. A significant question bearing both theoretical and practical implications, however, is whether emotional brand attachment or brand involvement is more apposite to warrant a luxury brand's performance and to safeguard the original brand from counterfeits, which remains unanswered. To address this knowledge gap, a survey was conducted. On the basis of an empirical study, this paper reveals that emotional brand attachment is a more prominent influencer than brand involvement to escalate original brand patronage although the effect of brand involvement is also significant. However, while improved brand involvement pushes consumers to patronize counterfeits, higher emotional brand attachment does not result in increased counterfeit patronage. These effects do not vary as a function of previous experience of either originals or counterfeits. Findings of this research contribute to brand literature by presenting empirical evidence of distinct influence of emotional brand attachment over brand involvement, which represents significant practical implications in relation to strategic brand management and anti-counterfeiting strategies.
\end{abstract}

Keywords Emotional brand attachment $\cdot$ Brand involvement $\cdot$ Past experience $\cdot$ Original luxury brands · Counterfeits . Consumer patronage

\section{Introduction}

Emotional brand attachment research has gained momentum in recent years. Research findings demonstrate that brand attachment leads to consumption behavior and a higher level of consumer loyalty, which provides a guarantee of sustainable financial performance (Park et al. 2010). Research also reports the feelings that a brand generates, which have the potential to differentiate one brand from another and consumers are usually emotionally attached to only a limited number of brands (Park et al. 2010). In practice, building emotional brand attachment with consumers has also increasingly become a strategic marketing endeavor of businesses, particularly in luxury brands (Cailleux et al. 2009; Theng et al. 2013). In contrast, brand involvement, a long-established concept, is also proven to have a significant

Sadia Haque

sadia.haque@northumbria.ac.uk

1 Northumbria University, Office - 417a, City Campus East 1, Newcastle upon Tyne NE1 8ST, UK effect on consumer decision-making and brand commitment (Mittal and Lee 1989). Developing and enhancing emotional brand attachment and brand involvement are both common strategies adopted by practitioners to improve performance. While the research findings support these marketing strategies, a critical question bearing significant theoretical and practical value remains unanswered: is emotional brand attachment more pertinent in determination of luxury brands' performance than brand involvement? Moreover, there is unprecedented upsurge of demand for counterfeits (OECD 2017) and in reality that luxury brands, the most affected by counterfeits (Wilcox et al. 2009), are fighting a losing battle despite the fact that they are increasingly investing in anti-counterfeiting (Bian 2018). Thus, when and how emotional brand attachment or brand involvement may be effective in eliminating demand for counterfeit luxury brands requires research attention.

Counterfeits have become a serious global problem in the last couple of decades, partially attributed to luxury brands that have been making branded products widely accessible and affordable via mass production. An estimation from the 
International Anti-Counterfeiting Coalition suggests that the value of global trade in counterfeiting and piracy in 2015 is US\$1.77 trillion (International Anti-Counterfeiting Coalition 2011). Among the affected, luxury brands alone lose a staggering US $\$ 600$ billion or more in 2014 (International Chamber of Commerce 2011). Counterfeits are a serious competitor and threat to original luxury branded products (originals hereafter).

The impact of counterfeits on originals include (but are not limited to): a reduction in consumers' confidence in legitimate brands, damage of brand equity and companies' reputations, loss of revenue, and increased costs associated with trying to contain infringement (Bian 2018). Businesses are teaming up with national and international governments to combat counterfeits. Nevertheless, counterfeits are more accessible than ever before. The Organization for Economic Co-operation and Development (OECD) reported that the global value of trade in counterfeit and pirated goods reached to US $\$ 461$ billion in 2013, which is more than over an 80 percent increase since 2008 (OECD 2016). According to an OECD (2019) report the figure mounted US $\$ 509$ billion in 2016 and may reach US $\$ 4.2$ trillion by 2022 . In the meantime, loss to luxury brands exceeded US $\$ 600$ billion to counterfeits in 2014 (Wu et al. 2019) compared to US\$12 billion reported in 2011 (International Chamber of Commerce 2011). Consumer demand for counterfeits, particularly in the luxury goods market, is one of the leading causes of the apparent growth of the counterfeiting phenomenon (Antonopoulos et al. 2017; Phau and Teah 2009; Bian and Veloutsou 2007; Gentry et al. 2001; Nia and Zaichkowsky 2000). When and what can be done to eliminate consumer demand for counterfeits, while in the meantime not causing damage to originals, is at the top of the brand protection agenda of many businesses (Evans et al. 2019; Wilson et al. 2016; Wilson 2017).

To address these issues, the objectives of this research are twofold: (1) to understand the theoretical implications and the relative impact of emotional brand attachment versus brand involvement on consumer original patronage as opposed to counterfeit patronage; and (2) to gain insights into whether the effect of emotional brand attachment versus brand involvement varies across consumers of different characteristics, namely original experience and counterfeit experience.

Previous research has demonstrated that emotional brand attachment better predicts brand loyalty and price sensitivity than attitude valance (Thomson et al. 2005). Park et al. (2010) have revealed that brand attachment and attitude strength have distinct effects and the former is a better indicator of consumer behavior. In the meantime, brand involvement, a construct of a rich research history, is also commonly accepted as a key antecedent to brand loyalty and performance. A more convincing case for the determinant power of emotional brand attachment thus can be made if its influence were significantly different to that of brand involvement. This research examines which is best to establish, emotional brand attachment or brand involvement, in order to enhance the performance of originals and simultaneously to manage consumer patronage of counterfeits. Findings in this area will bring substantial contribution to the emotional brand attachment literature and strategic brand management. According to the systematic review we conducted, a comprehensive understanding of the comparative advantages in relation to creating strong emotional brand attachments rather than increasing brand involvement among consumers of different characteristics is scarce; the second research objective is especially relevant and important for marketing practitioners in providing guidance on which strategy to use in a particular situation.

To this end, the novelties of this research include: (1) first of a kind to propose and analyze the competitive advantages concerning developing emotional brand attachment versus brand involvement in relation to originals; (2) one of the few to unveil possible outcomes associated with two commonly adopted but distinct branding strategies, namely improving brand involvement and establishing emotional brand attachment, in addressing consumer demand for counterfeits. The findings of this research, therefore, advances Kaufmann et al. (2016) who revealed the desirable effect of emotional brand attachment on elimination of demand for counterfeits; (3) while extant research has examined the direct effect of availability and past experience on demand for both originals and counterfeits (e.g., Yoo and Lee 2012), this research investigates impact of past experience of counterfeits and originals as a boundary condition on consumer patronage.

This paper first presents an overview of relevant literature and hypotheses tested. The literature review mainly covers emotional brand attachment, brand involvement, and counterfeit-related research, followed by an outline of the research methods employed to address the research objectives. The research results are subsequently presented. This paper concludes with a discussion of the key findings, the theoretical and practical implications, and suggestions for future research.

\section{Literature and hypotheses}

\section{Emotional brand attachment}

In psychology, attachment is an emotion-laden targetspecific bond between an individual and a specific object (Bowlby 1979). Desire to develop strong emotional attachment with particular others serves basic human needs, such as social and esteem desires (Bowlby 1980; Ainsworth et al. 1978). In a marketing context, consumers are also inclined 
to build and maintain emotionally charged associations with brands (Belk 1988; Schouten and McAlexander 1995; Fournier 1998). Emotional brand attachment, introduced by Thomson et al. (2005), reflects the bond between a consumer and a specific brand and involves feelings toward the brand (Shimul et al. 2019; Fastoso and González-Jiménez 2018). Emotional brand attachments are positively associated with feelings of unique dimensions, namely connection, affection and passion (Thomson et al. 2005).

Similar to the attachment concept in psychology, emotional brand attachment varies in strength and has prominent influence on consumer behavior. Thomson et al. (2005) have reported that the more strongly consumers are emotionally attached to a brand, the more likely they are to be loyal to the brand and willing to pay a price premium. In the same vein, Park et al. (2010) have demonstrated that brand attachment is a significant predictor of behaviors. Specifically, the more strongly consumers are attached to a brand, the more willing they are to engage in challenging behaviors, such as those requiring investment of time, money, energy, and reputation. Therefore, it is rational to posit that in a market where counterfeits are openly accessible, the more strongly the emotional bond consumers perceive toward an original luxury brand, the more likely they will purchase the original.

How would emotional brand attachment affect consumers' patronage of counterfeits? Limited research has been done to address this both theoretically and practically important question with one exception of Kaufmann et al. (2016), which reports that emotional brand attachment has a negative effect on the purchase intention of counterfeit handbags. In line with this finding, this paper posits that the influence of emotional brand attachment on counterfeit patronage is likely to be negative. Counterfeits are illegal products that use the trademark of the originals but are made without the permission of the trademark holder (Chaudhry and Walsh 1996). These illegally produced products are invaders and competitors and cause misfortune to the originals (Marticotte and Arcand 2017), which subsequently induce threats to consumers who are emotionally bonded to the original brand. Attachment theory suggests that individuals who are strongly attached to a person or object possess two unique characteristics: they display specific behaviors such as proximity maintenance and separation distress (Bowlby 1979) and they are committed to preserving their relationship with the person or object (Johnson and Rusbult 1989; Miller 1997). This is because a strong emotional attachment is characterized by a perception that the object is irreplaceable. From a brand perspective, consumers of a high level of emotional brand attachment tend to incorporate a brand as part of their self and hold salient feelings about the brand and are more willing to forego personal resources to maintain a relationship with the brand (Park et al. 2010). Therefore, the stronger the emotional brand attachment is the more likely consumers will defend the brand against other alternatives available in the market, including counterfeits. Based on these considerations, consumers of a high level of emotional brand attachment are more likely to disapprove of counterfeits. This research, thus, proposes:

$\mathbf{H}_{1}$ Emotional brand attachment has a positive effect on consumer original patronage.

$\mathbf{H}_{\mathbf{2}}$ Emotional brand attachment has a negative effect on consumer counterfeit patronage.

\section{Brand involvement}

Involvement is "a person's perceived relevance of the object based on inherent needs, values and interests" (Zaichkowsky 1985,342 ) and is a mental state that influences the allocation of cognitive resources to evaluation of an object, decision, or action (Mittal and Lee 1989). Product involvement is the most researched construct and it has been established that the level of involvement determines the depth, complexity and extent of cognitive and behavioral processes during the consumer choice process (Kokkinaki 1999; Chakravarti and Janiszewski 2003; Kleiser and Wagner 1999; Kapferer and Laurent 1985; Rothschild and Houston 1980; Feng et al. 2019; Friedmann and Lowengart 2019; Stewart et al. 2019; Alonso-Dos-Santos et al. 2019). Therefore, product involvement is a central framework, vital to understand consumer decision-making (Chakravarti and Janiszewski 2003; Fill 2005) and is an important contingency variable for the success of marketing strategies (MacInnis and Park 1991; Petty and Cacioppo 1986). Previous researchers (Kirmani et al. 1999; Bloch 1982; Bloch and Richins 1983; Zaichkowsky 1985, 1986; Mittal and Lee 1988) have distinguished product involvement from brand involvement and has long established that product involvement and brand involvement are distinct constructs (e.g., Bloch and Richins (1983). Surprisingly, brand involvement, the consumer's degree of interest or arousal for a given brand, has not received much research attention in the counterfeit context. Bian and Moutinho (2011) and Bian (2006) have studied the effects of product involvement on consumer decision-making and purchase tendency of counterfeits and originals. Neither of these articles, however, explores the possible influence of brand involvement on consumer behavioral strategies toward originals versus counterfeits, which leaves a knowledge void of substantial importance.

Involvement is fundamental to the Elaboration Likelihood Model (Petty and Cacioppo 1986) which posits that high involvement tends to engender a central route to persuasion, in which consumers exert the cognitive effort to evaluate the issue when relevant objects or arguments are presented to them. Consumers with high involvement will be more 
motivated to invest time and the cognitive effort required for self-verification. In contrast, a low level of involvement would create low consumer motivation to process information, which leads to a greater possibility of the peripheral route of persuasion. When involvement is low, consumers care less about personal, experiential, and symbolic gain than when involvement is high (Solomon et al. 1985).

The premise of this paper is that the principles of the seminal Elaboration Likelihood Model (Petty and Cacioppo 1986) are also applicable to brand involvement. Therefore, it is rational to posit that brand involvement is likely to have a positive effect on consumer patronage of originals because higher brand involvement will drive consumers to go through more deliberative decision-making which will enable them to be more appreciative to not only functional benefits but also hedonic gains from originals. This is due to the original version of branded products being commonly recognized as superior in their values (signal, hedonic, and functional). In contrast, brand involvement will negatively affect consumer patronage of counterfeits, because the lower the brand involvement, the more likely consumers will make quick decisions, which require little to limited effort. Hence, counterfeits are more likely to be acted upon in the low brand involvement situation because consumers are less attentive to the core attributes of a brand, such as high quality (Cheah et al. 2015), instead they tend to purchase impulsively and would be responsive to brand names. In other words, the prominent brand name and logo copied by counterfeits may serve as the peripheral cues of persuasion. In addition, the low-price tag, a key feature, of counterfeits (Eisend et al. 2017; Eisend and Schuchert-Güler 2006) is also likely to serve as another key peripheral cue which lure consumers to counterfeits when brand involvement is low. Based on the above reasoning, this research proposes the following:

$\mathbf{H}_{\mathbf{3}}$ Brand involvement has a positive effect on consumer original patronage.

$\mathbf{H}_{\mathbf{4}}$ Brand involvement has a negative effect on consumer counterfeit patronage.

\section{Comparative effect of emotional brand attachment and brand involvement}

If $\mathrm{H}_{1}-\mathrm{H}_{2}$ and $\mathrm{H}_{3}-\mathrm{H}_{4}$ hold and emotional brand attachment and brand involvement have positive effects on consumer original patronage but negative influences on counterfeit patronage, the next viable questions are:

1. Is any one of the two determinants more influential than the other?

2. Which one is more statistically effective in enhancing/ eliminating demand for originals/counterfeits?
Brand involvement is conceptually distinguished from emotional brand attachment. Involvement is a state of mental readiness that influences the allocation of cognitive resources (Park and Mittal 1985). The concept of involvement arguably represents consumers' perceptual and conceptual responses, which mainly tap the realm of cognition (Zaichkowsky 1985). Emotional attachment, however, goes beyond mental readiness and resource allocation. Emotional brand attachments are consumers' affective reactions toward a brand and, thus, are clearly relevant to the realm of emotions (Thomson et al. 2005). While involvement represents a manifestation of one's volitional control (Bowlby 1980; Hazan and Zeifman 1999), emotional brand attachment is a reflection of one's affections.

Emotional attachment is inherently related to the consumers' self-concept (Park et al. 2010, Kleine et al. 1993). The more attached consumers are to a brand, the more likely they would view the brand as part of themselves and have salient feelings about the brand. As a result, they are more likely to be willing to maintain proximity to the brand even at a higher cost than they normally retain. The effects of brand involvement on consumer behavior should be relatively weaker than emotional brand attachment. This is because brand involvement, although a self-centered construct (Laaksonen 1994), is not directly connected to consumer' self-concept, which consumers usually protect at all cost. Thus, emotional brand attachment (compared to brand involvement) should show stronger influence on the tendency of maintaining a brand relationship, manifested through patronage of originals. The same reasoning is likely to be applicable to counterfeits. This research, thus, anticipates the following:

$\mathbf{H}_{\mathbf{5}}$ Emotional brand attachment has a stronger effect on consumer original patronage than brand involvement.

$\mathbf{H}_{6}$ Emotional brand attachment has a stronger effect on consumer counterfeit patronage than brand involvement.

\section{Moderating effects}

It is important to note that the hypothesized effects in $\mathrm{H}_{1}$ through $\mathrm{H}_{4}$ may not be equally pronounced for all consumers. This research predicts that these effects might be stronger for consumers with certain predispositions. Specifically, this research is interested in the possible moderating effect of original experience and counterfeit experience on the relationships between emotional brand attachment/brand involvement and original/counterfeit patronage.

As outlined in the context of $\mathrm{H}_{1}$ to $\mathrm{H}_{4}$, emotional brand attachment (brand involvement) increases (decreases) original (counterfeit) patronage because the more attached (interested) consumers are to a brand the more likely they would be committed to the original brand. Manifestations 
of a higher level of commitment range from higher brand loyalty and willingness to make financial sacrifices to deny other competing brands (Park et al. 2010) including counterfeits. However, this effect might vary between consumers of low and high original/counterfeit experience. While previous research has investigated the direct effect of past experience on both originals and counterfeits, for example Yoo and Lee (2012), how consumer patronage might vary as a function of past experience remains largely unknown. This is particularly the case in relation to counterfeits.

Product experience has important implications for consumer information processing and behavior. According to Hill and Alexander (2006), a consumer's purchase behavior of a product is determined by the level of their experience of the product. Similarly, Lianto (2015) has demonstrated that past experience affects consumer purchase intention of a product. As long as circumstances remain stable, experience has a stronger influence on behavior than cognitive consideration (Bamberg et al. 2003; Hill and Alexander 2006; Yoo and Lee 2009) and perceived behavioral control (Bagozzi 1981; Ouellette and Wood 1998; Yoo and Lee 2009, 2012). In addition, habitual behavior literature suggests that experience is one of the key antecedences of a habit (Schneider and Shiffrin 1977). Repeated experience will result in habitual behavior, which people are able to perform with little burden (Schneider and Shiffrin 1977; Lianto 2015). Past experience generates an inertial habit with repeated behavior and predicts future behavior better than cognitive evaluations of alternatives do (Bamberg et al. 2003). Seetharaman et al. (1999) has confirmed that inertial choice behavior formed by past experience makes consumers repeat the same purchase patterns and is less sensitive to marketing programs developed to change such decision-making.

According to the empirical findings of product experience and habitual behavior literature, consumers with a high level of original experience (compared with consumers with a low level of original experience) are likely to demonstrate different reactions to originals/counterfeits. In addition, these consumers would be more familiar with the superiorities (e.g., benefits and advantages) associated with the originals, which might subsequently further enhance the effects of both emotional brand attachment and brand involvement on original/counterfeit patronage. For consumers with a low level of original experience, benefits associated with the originals might be more distant and abstract, thus appearing to be less distinct, which would subsequently mitigate the influence of emotional brand attachment and brand involvement. The current research, thus, proposes:

$\mathbf{H}_{\mathbf{7 a}}$ Past original experience strengthens the relationship between emotional brand attachment and original patronage.
$\mathbf{H}_{\mathbf{7 b}}$ Past original experience strengthens the relationship between emotional brand attachment and counterfeit patronage.

$\mathbf{H}_{\mathbf{7 c}}$ Past original experience strengthens the relationship between brand involvement and original patronage.

$\mathbf{H}_{\mathbf{7 d}}$ Past original experience strengthens the relationship between brand involvement and counterfeit patronage.

Will counterfeit experience influence consumer patronage of originals as well as counterfeits? Consumers with a high level of counterfeit experience might be more appreciative to relative benefits associated with counterfeits. Previous research findings suggest that consumers with counterfeit experience have a more positive attitude toward counterfeits than consumers who have little experience (Nia and Zaichkowsky 2000). Counterfeit evaluations of experienced consumers are more positive than less experienced consumers (Penz and Stöttinger 2008; Moon et al. 2018). Yoo and Lee (2009) have also presented empirical evidence that past experience of counterfeits and original branded products have a positive influence on purchase intention of counterfeits and originals. The possible explanation is that consumers with more experience of counterfeits are inclined to believe that the functionalities of counterfeits are close to originals (Bian et al. 2016); thus, they attribute "value for money" to counterfeits (de Matos et al. 2007). These perceived benefits of counterfeits evolved from past experience are likely to mitigate the impacts of emotional brand attachment and brand involvement on consumer product patronage, originals and counterfeits. In other words, the effect of emotional brand attachment (brand involvement) on original and counterfeit patronage will both be reduced. Based on this reasoning this research predicts a moderation effect of counterfeit experience on the relationship between emotional brand attachment (brand involvement) and counterfeit (original) patronage. The proposed relationships are:

$\mathbf{H}_{\mathbf{8 a}}$ Past counterfeit experience weakens the relationship between emotional brand attachment and original patronage.

$\mathbf{H}_{\mathbf{8 b}}$ Past counterfeit experience weakens the relationship between emotional brand attachment and counterfeit patronage.

$\mathbf{H}_{\mathbf{8 c}}$ Past counterfeit experience weakens the relationship between brand involvement and original patronage.

$\mathbf{H}_{\mathbf{8 d}}$ Past counterfeit experience weakens the relationship between brand involvement and counterfeit patronage. 
Figure 1 presents the conceptual framework of this research. Both emotional brand attachment and brand involvement affect consumer's original as well as counterfeit patronage. However, the influence of these determinants may vary, depending on the consumers' level of previous engagement with originals and counterfeits, specifically past experience. This research also analyzes comparative effect of emotional brand attachment versus brand involvement.

\section{Method}

\section{Data collection and sample}

To test the hypotheses data were collected using a paper and pencil survey method from Chinese consumers in shopping malls of China which are known for selling counterfeits openly. The choice of China, Beijing specifically, as the research context is because China is one of the largest markets for luxury brands (Cheung and Prendergast 2006) and is also the largest consumer market of counterfeits in the world (OECD and EUIPO 2019). On one hand, consumers crave original luxury brands and are happy to pay a premium price for originals (Vigneron and Johnson 2004), and on the other hand, counterfeits are also commonly acceptable to Chinese consumers (Cheung and Prendergast 2006). About a decade ago, Swike et al. (2008) have reported that approximately twenty percent of domestic sales in China are counterfeits. The situation has very likely worsened in recent years in light of the increased accessibility of counterfeits. In fact, counterfeits have dedicated shopping areas in many major cities (Lin 2011), such as the Yanghuo Market in Tianjin and Silk Market in Beijing.

Two hundred and sixty-six Chinese consumers were invited to take part in this research. All collected questionnaires were useable. Respondents consisted of consumers aged between 19 and 54 (43.6\% females, 56.4\% males). The education attainment of respondents ranged between primary school and postgraduate degree. The sample (see "Appendix 1" for respondents' profile) included consumers of low household income (less than RMB $¥ 10,000$ per month) to high household income (above RMBY200,000 per month).

Before the respondents started filling out the questionnaires, they were informed that a large percentage of consumers knowingly purchase counterfeits, including consumers in developed countries, such as the UK and the USA. This measure, adopted by a number of previous studies where China was the research context (e.g., Veloutsou and Bian 2008; Wilhelmy et al. 2016; Bian et al. 2016), was used mainly to eliminate impression management tendency and to safeguard quality of data. This is because the technique is deemed to induce a respondent's admission of potentially embarrassing behavior (Churchill and Iacobucci 1999). Additionally, respondents were assured that the information they provided would be kept strictly confidential and for academic research purposes only. As with Bian (2006) and Bian and Moutinho (2011), the definition of counterfeit was presented at the very beginning of the questionnaire to reduce confusion and more importantly to ensure data reliability. This research is particularly interested in original luxury brand versus counterfeit luxury brand-related consumer behavior. To capture relevant data, participants were referred to examples of high-end luxury brands, such as, Louis Vuitton and Hermes. All the referred luxury brands are widely available and heavily counterfeited. The questionnaire took less than 20 minutes to complete.

\section{Measures}

Emotional brand attachment was assessed using six items adapted from measures previously used in consumer research
Fig. 1 Proposed framework linking emotional brand attachment, brand involvement, consumer original and counterfeit patronage

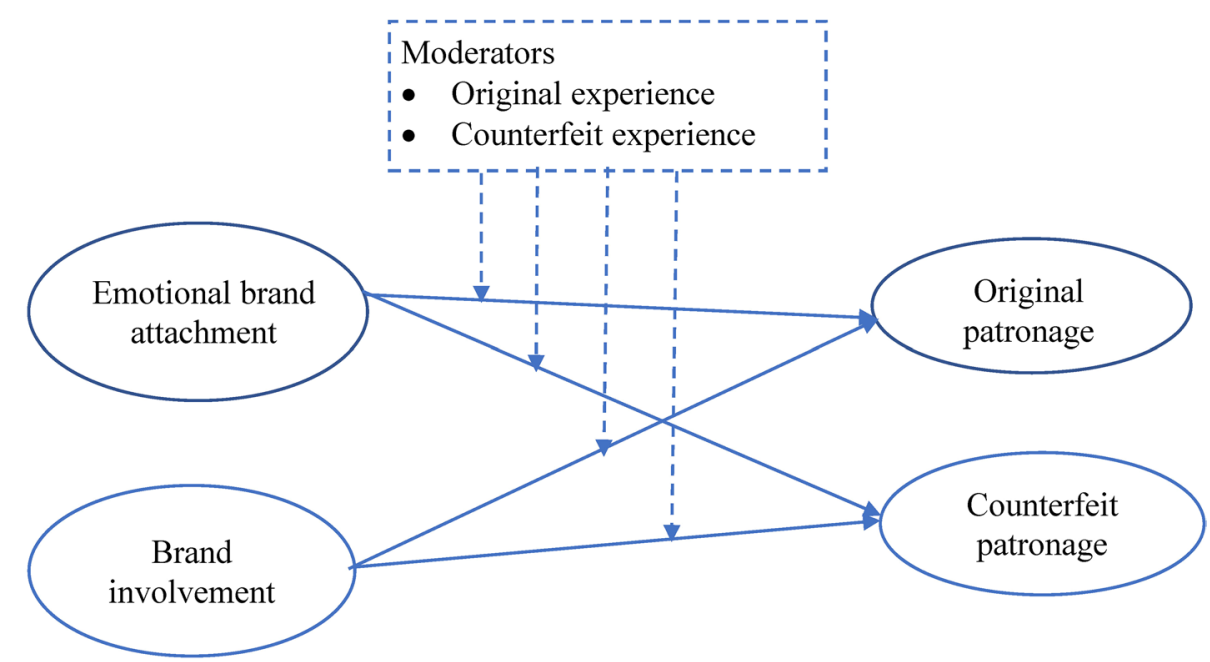


from Malär et al. (2011). These items are highly correlated (Cronbach $\alpha=.89$ ) and capture three main dimensions of emotional bond with brands, namely affection, connection, and passion (Thomson et al. 2005). The brand involvement variable was measured with two items $(r=.81)$ adapted from Trijp et al. (1996). This measure is appropriate because it was developed based on the involvement definition which falls within the domain of cognitive approaches by defining involvement (Laaksonen 1994). The moderating variables (original experience and counterfeit experience) were both measured using a semantic differential scale (seven-point, ranging from never to regular) adapted from Darmon and Laroche (1991). Whenever appropriate, multiple items were averaged to arrive at a single value for each variable. These average values are input indicators.

The dependent variables of counterfeit patronage $(r=.89)$ and original patronage $(r=.86)$ were measured using two items adopted from Zhao et al. (2013) and Grewal et al. (1998). Unless noted otherwise, all multi-item scales were

Table 1 Correlations of framework variables

\begin{tabular}{llllll}
\hline & 1 & 2 & 3 & 4 & 5 \\
\hline $\begin{array}{l}\text { 1. Emotional brand attach- } \\
\text { ment }\end{array}$ & & & & & \\
2. Brand involvement & $.48^{* *}$ & & & & \\
3. Original patronage & $.51^{* *}$ & $.38^{* *}$ & & & \\
4. Counterfeit patronage & .11 & $.17^{* *}$ & -.009 & & \\
5. Original experience & $.22^{* *}$ & .04 & $.29^{* *}-.17^{* *}$ & \\
6. Counterfeit experience & .01 & .06 & $-.14^{*}$ & $.34^{* *}$ & $-.18^{* *}$ \\
\hline
\end{tabular}

$* p \leq .05$

$* * p \leq .01$ assessed using a seven-point Likert format (strongly disagree to strongly agree). Personal information about respondents' gender, monthly household income, age, and highest education attainment was also collected at the end of the research instrument. In general, the measurements show sufficient reliability. Table 1 reports the correlations of the conceptual framework variables. "Appendix 2" provides a list of the measures and their psychometric properties.

\section{Results}

\section{Basic model}

AMOS 25 path analysis was used to model the relationships proposed by the conceptual framework (see Fig. 1). Emotional brand attachment and brand involvement were allowed to correlate in the path model. For the basic model (presented using solid lines), the measures of overall fit generally meet conventional standards, which suggests that the model fits the data well $\left(\chi^{2} / d f=2.880\right.$, root mean square error of approximation [RMSEA] $=.084$, standardized root mean square residual $[$ SRMR] $=.027$, normal fit index $[\mathrm{NFI}]=.983$, and comparative fit index $[\mathrm{CFI}]=.989$ ).

The parameter estimates of the basic model are reported in Table 2. The results suggest a significant positive relationship between emotional brand attachment and consumer original patronage $(Y=.426, p<.01)$, which supports $\mathrm{H}_{1}$. The results provide no support for a negative relationship between emotional brand attachment and consumer counterfeit patronage $(Y=.035, p>.10)$, which rejects $\mathrm{H}_{2}$. Brand involvement has a significant positive effect on original patronage $(Y=.176, p<.01) . \mathrm{H}_{3}$ is

Table 2 Results of hypotheses testing

\begin{tabular}{|c|c|c|c|c|c|c|c|c|c|}
\hline & & \multicolumn{2}{|c|}{$\begin{array}{l}\text { Emotional brand } \\
\text { attachment } \rightarrow \text { original } \\
\text { patronage }\end{array}$} & \multicolumn{2}{|c|}{$\begin{array}{l}\text { Brand involve- } \\
\text { ment } \rightarrow \text { original patron- } \\
\text { age }\end{array}$} & \multicolumn{2}{|c|}{$\begin{array}{l}\text { Emotional brand attach- } \\
\text { ment } \rightarrow \text { counterfeit } \\
\text { patronage }\end{array}$} & \multicolumn{2}{|c|}{$\begin{array}{l}\text { Brand involve- } \\
\text { ment } \rightarrow \text { counterfeit } \\
\text { patronage }\end{array}$} \\
\hline & & $\begin{array}{l}\text { Standardized } \\
\text { Estimate }(t \\
\text { value })\end{array}$ & $\Delta x^{2}$ & $\begin{array}{l}\text { Standardized } \\
\text { Estimate }(t \\
\text { value })\end{array}$ & $\Delta x^{2}$ & $\begin{array}{l}\text { Standardized } \\
\text { Estimate }(t \\
\text { value })\end{array}$ & $\Delta x^{2}$ & $\begin{array}{l}\text { Standardized } \\
\text { Estimate }(t \\
\text { value })\end{array}$ & $\Delta x^{2}$ \\
\hline \multicolumn{10}{|l|}{ Basic model } \\
\hline & & $.426 * *(7.192)$ & & $.176 * *(2.973)$ & & $.035(.513)$ & & $.156^{*}(2.254)$ & \\
\hline \multicolumn{10}{|l|}{ Moderated models } \\
\hline Experience of originals & $\begin{array}{l}\text { Low } \\
\text { High }\end{array}$ & $\begin{array}{l}.332 * *(3.456) \\
.441 * *(6.054)\end{array}$ & 2.715 & $\begin{array}{l}.143(1.488) \\
.212 * *(2.801)\end{array}$ & 2.238 & $\begin{array}{l}.039(.705) \\
.075(.813)\end{array}$ & 2.176 & $\begin{array}{l}.187^{+}(1.814) \\
.131(1.408)\end{array}$ & 2.077 \\
\hline Experience of counterfeits & $\begin{array}{l}\text { Low } \\
\text { High }\end{array}$ & $\begin{array}{l}.448 * *(6.306) \\
.394 * *(3.770)\end{array}$ & .861 & $\begin{array}{l}.238 * *(3.349) \\
.086(.826)\end{array}$ & 1.912 & $\begin{array}{l}.067(.773) \\
.027(.233)\end{array}$ & .925 & $\begin{array}{l}.134(1.547) \\
.195^{+}(1.709)\end{array}$ & 1.064 \\
\hline
\end{tabular}

\footnotetext{
$* * p \leq .01$

$* p \leq .05$

${ }^{+} p \leq .10$ 
supported. The results suggest a significant relationship between brand involvement and consumer counterfeit patronage $(Y=.156, p<.05)$. Surprisingly, the effect is positive rather than negative as predicted, which rejects $\mathrm{H}_{4}$.

The values of these two path coefficients provide support for the propositions regarding the relative impact of emotional brand attachment and brand involvement on original patronage as well as counterfeit patronage. For original patronage, emotional brand attachment has a stronger impact on original patronage than brand involvement. For counterfeit patronage, brand involvement effect, however, is more evident than emotional brand attachment. The corresponding differences are .250 (original patronage) and .121 (counterfeit patronage).

In order to test the $\mathrm{H}_{5}$ that the emotional brand attachment $(Y=.426)$ and brand involvement $(Y=.176)$ standardized beta weights were statistically different from each other, their corresponding 95\% confidence intervals were estimated via bias corrected bootstrap (1000 re-samples). In the event that the confidence intervals overlapped by less than $50 \%$ the weights would be considered significantly different $(p<.05)$ from each other (Cumming 2009). Half of the average of the overlapping confidence intervals was calculated (-.0045) and added to the lower bound estimate of the emotional brand attachment beta weight (.310) which yielded .3055. As the brand involvement upper bound estimate of .290 is lower than the value of .3055 , in the original context, the difference between the emotional brand attachment and brand involvement standardized beta weights $(\Delta Y=.25)$ is considered significantly larger than the brand involvement beta weight $(p<.05)$. Thus, emotional brand attachment has a stronger effect on consumer original patronage than brand involvement, which supports $\mathrm{H}_{5}$.

Similarly, to test the $\mathrm{H}_{6}$ that the brand involvement $(Y=.156)$ and emotional brand attachment $(Y=.035)$ standardized beta weights were statistically different from each other, their corresponding 95\% confidence intervals were estimated via bias corrected bootstrap (1000 re-samples). Half of the average of the overlapping confidence intervals was calculated (-.010) and added to the lower bound estimate of the brand involvement beta weight (.029) which yielded .019. As the emotional brand attachment upper bound estimate of .172 is higher than the value of .019 , in the counterfeit context, the difference between the brand involvement and emotional brand attachment standardized beta weights $(\Delta Y=.121)$ is not considered statistically significantly larger than the emotional brand attachment beta weight $(p>.05)$. Therefore, the result suggests that emotional brand attachment does not have a stronger effect on consumer counterfeit patronage than brand involvement, which rejects $\mathrm{H}_{6}$.

\section{Moderating model: original experience as moderator}

Multiple group modeling was used to test $\mathrm{H}_{7}$ and $\mathrm{H}_{8}$, which refer to the moderating role of original experience and counterfeit experience. The median of the moderator values was used to split consumers into either low levels or high levels of original experience. AMOS 25 was used to test the moderated model suggested in the conceptual framework simultaneously in both subsamples. Table 2 presents the parameter estimates for the different subgroups.

Regarding the first moderator, original experience, the measures of overall fit of the moderated model mostly meet conventional standards, which suggests that the model fits the data well $\left(\chi^{2} / d f=2.048, \mathrm{RMSEA}=.010, \mathrm{SRMR}=.022\right.$, $\mathrm{NFI}=.988$, and $\mathrm{CFI}=1.000$ ). As with consumer original patronage, the results confirm a positive moderating effect of original experience on the relationship between emotional brand engagement and original patronage. Although emotional brand attachment has a significant and positive effect on original patronage among consumers with a low level of original experience $(Y=.332, p<.01)$ this effect becomes stronger among consumers with a high level of original experience $(Y=.458, p<.01)$. To statistically test the significance of this moderating effect, a Chi square difference test was run. The Chi square difference is not significant at the .10 level $\left(\Delta x^{2}=2.715, \Delta d . f .=3, p>.10\right)$. This result rejects $\mathrm{H}_{7 \mathrm{a}}$. Past experience of originals has no significant impact on relationship between emotional brand attachment and original patronage.

Emotional brand attachment has no significant effect on counterfeit patronage among consumers with a low level of original experience $(Y=.039, p>.10)$. This effect, although becomes slightly stronger among consumers with a high level of original experience $(\Upsilon=.075, p>.10)$, is insignificant. To statistically test the significance of this moderating effect, a Chi square difference test was run. The Chi square difference is not significant at the .10 level $\left(\Delta x^{2}=2.176\right.$, $\Delta d . f .=3, p>.10$ ). This result rejects $\mathrm{H}_{7 \mathrm{~b}}$, which suggests that relationship between emotional brand attachment and counterfeit patronage does not vary as a function of past experience of originals.

Brand involvement has a significant and positive effect on original patronage only among consumers with a high level of original experience $(Y=.212, p<.01)$ and no significant effect among consumers with a low level of original experience $(Y=.143, p>.10)$. The Chi square difference is not significant at the .10 level $\left(\Delta x^{2}=2.238, \Delta d . f .=3, p>.10\right)$, which rejects $\mathrm{H}_{7 \mathrm{c}}$. Thus, past experience of originals has no significant impact on relationship between brand involvement and original patronage.

Brand involvement shows a marginally significant and positive effect on counterfeit patronage only among 
consumers with a low level of original experience $(Y=.187$, $p=.070)$ and no significant effect among consumers with a high level of original experience $(Y=.131, p>.10)$. The Chi square difference is not significant at the .10 level $\left(\Delta x^{2}=2.077, \Delta d . f .=3, p>.10\right)$, which rejects $\mathrm{H}_{7 \mathrm{~d}}$. This result suggests that past experience of originals does not affect relationship between brand involvement and counterfeit patronage.

\section{Moderating model: counterfeit experience as moderator}

Regarding the second moderator, counterfeit experience, the measures of overall fit of the moderated model mostly meet conventional standards, which suggests that the model fits the data well $\left(\chi^{2} / d f=.849\right.$, RMSEA $=.000$, SRMR $=.016$, $\mathrm{NFI}=.995$, and $\mathrm{CFI}=1.000)$. As with consumer original patronage, the results confirm a positive moderating effect of counterfeit experience on the relationship between emotional brand engagement and original patronage. Although emotional brand attachment has a significant and positive effect on original patronage among consumers with a low level of original experience $(Y=.448, p<.01)$ this effect becomes slightly weaker among consumers with a high level of counterfeit experience $(Y=.394, p<.01)$. To statistically test the significance of this moderating effect, a Chi square difference test was run. The Chi square difference is not significant at the .10 level $\left(\Delta x^{2}=.861, \Delta d . f .=3, p>.10\right)$. This result rejects $\mathrm{H}_{8 \mathrm{a}}$. Thus, past experience of counterfeits has no significant impact on relationship between emotional brand attachment and original patronage.

Emotional brand attachment has no significant effect on counterfeit patronage among consumers with a low level of counterfeit experience $(Y=.067, p>.10)$. This effect becomes slightly weaker among consumers with a high level of original experience $(Y=.027, p>.10)$ and is insignificant. To statistically test the significance of this moderating effect, a Chi square difference test was run. The Chi square difference is not significant at the .10 level $\left(\Delta x^{2}=0.925\right.$, $\Delta d . f .=3, p>.10$ ). This result rejects $\mathrm{H}_{8 \mathrm{~b}}$. This result reveals that past experience of counterfeits does not significantly affect relationship between emotional brand attachment and counterfeit patronage.

Brand involvement has a significant and positive effect on original patronage only among consumers with a low level of counterfeit experience $(Y=.238, p<.01)$ and no significant effect among consumers with a high level of counterfeit experience $(Y=.086, p>.10)$. The Chi square difference is not significant at the .10 level $\left(\Delta x^{2}=1.912\right.$, $\Delta$ d.f. $=3, p>.10$ ), which does not support $\mathrm{H}_{8 \mathrm{c}}$. This result suggests that past counterfeit experience has no significant impact on relationship between brand involvement and original patronage.
Brand involvement has a marginally significant and positive effect on counterfeit patronage only among consumers with a high level of counterfeit experience $(Y=.195$, $p=.087$ ) but no significant effect among consumers with a low level of counterfeit experience $(Y=.134, p>.10)$. The Chi square difference is not significant at the .10 level $\left(\Delta x^{2}=1.064, \Delta d . f .=3, p>.10\right)$, which rejects $\mathrm{H}_{8 \mathrm{~d}}$. This result advises that past experience of counterfeit does not affect relationship between brand involvement and counterfeit patronage.

\section{Discussion and conclusion}

\section{Theoretical implications}

Building on existing emotional brand attachment and brand involvement literature (e.g., Dunn and Hoegg 2014; Park et al. 2010; Thomson et al. 2005; Mittal and Lee 1989; Leckie et al. 2016) this research makes substantial theoretical contributions. While the literature has established the prominent role played by emotional brand attachment in determination of brand performance (e.g., Japutra et al. 2018; Hung and Lu 2018; Japutra et al. 2014), the comparative strength of influence of emotional brand attachment versus brand involvement, the two most pertinent concepts on consumption behavior of originals remained underexplored. Therefore, until this current research little knowledge existed in the literature in terms of comparative advantages/ disadvantages of building emotional brand attachment as opposed to brand involvement. This knowledge gap is surprising as emotional brand attachment and brand involvement are both important contingency variables for the success of branding strategy and until comparative advantages are unveiled understanding of outcomes of emotional brand attachment would remain incomplete. This research is one of the first which reveals that emotional brand attachment plays a more dominant role compared to brand involvement in determining consumer patronage of originals. The findings of this research bridge a substantial knowledge void and advance the debate by presenting empirical evidence of the distinct influence of emotional brand attachment and brand involvement.

Differing to Kauffman et al. (2016) which reports a negative effect of emotional brand attachment on counterfeit purchase intention, the findings of this research suggest otherwise. Specifically, emotional brand attachment has no statistically significant impact on consumer counterfeit patronage. These differences could be attributed to distinct research contexts as well as brands examined. Kauffman et al. (2016) was conducted in Brazil and data was collected from a homogeneous female population, whereas data of this research was collected from Chinese consumers, including 
males and females. These inconsistent findings imply that effect of emotional brand attachment is very likely to be context specific, which also opens a new avenue for future research.

The findings of this research reveal a positive influence of brand involvement on counterfeit patronage. This finding is surprising because the relevant literature indicates a negative (rather than positive) effect of brand involvement on counterfeit purchase intention. The possible explanation to this unexpected finding is that consumers are attracted to excitements associated with the counterfeit's purchasing process (e.g., the thrill of the hunt), belongingness (e.g., being part of a secret society), and personal interest in counterfeits (Bian et al. 2016), all of which are brand involvement essentials. Acknowledging that much has been done in recent years in study of counterfeit-related consumption behavior, taking a novel brand management strategy perspective this research advances the understanding of competitive advantages of emotional brand attachment versus brand involvement methods in relation to protecting originals from their counterparts, namely counterfeits. The findings of this research are one of the first which provide empirical evidence that improving brand involvement would contribute to demand for counterfeits. In contrast, enhancing emotional brand attachment is unlikely to result in undesirable impact.

This research also contributes to the literature through testing boundary conditions of emotional brand attachment and brand involvement effect on both originals and counterfeits. Specifically, differing to most of prior studies this research explores the indirect rather than the direct effect of past experience. The findings suggest that effect of emotional brand attachment and brand involvement do not vary as a function of past experience of either originals or counterfeits. This research is one of the few, which provides empirical evidence and rules out the possible moderating effects of past experience on the relationships between emotional brand attachment/brand involvement and original/ counterfeit patronage.

\section{Managerial implications}

From a practical implication perspective, the findings of this research are of significant importance to managers. Specifically, according to the findings, emotional brand attachment plays a more dominant role than brand involvement in determining consumer patronage of originals. Thus, when a company is strategizing to enhance its brand performance, although both will lead to positive results, focusing on establishing a stronger emotional brand attachment will result in a better outcome (statistically significant) compared to that of brand involvement. To this end, practitioners could implement the following four methods (Malär et al. 2011): incorporation of consumers' selves, focusing on authentic branding, reconsidering aspirational branding, and individualizing branding efforts. This research also suggest that increased emotional brand attachment will improve brand performance but does not escalate consumer counterfeit patronage. However, increased brand involvement although leads to higher demand for originals, it also results in increased consumer patronage of counterfeits. Therefore, to enhance brand performance and in the same time to protect brand equity from counterfeits, originals also need to particularly focus on building emotional brand attachment over brand involvement with their consumers.

The findings related to the effect of past experience on consumer patronage of originals and counterfeits are very important and highly relevant to practitioners considering the fact that counterfeits are getting more openly accessible to consumers both online and offline (Jin 2012; Antonopoulos and Hall 2018). In addition, a growing number of consumers are inclined to purchase counterfeits (Bian 2018), which will undoubtedly result in an increasing level of counterfeit experience among consumers. Original intellectual property owners are very concerned that increased consumer counterfeit experience might largely mitigate marketing endeavors. Despite the concern of practitioners, the findings of this research suggest that the level of previous experience of either originals or counterfeits have no significant impact on relationship between emotional brand attachment/ involvement and consumer patronage of originals/counterfeits. These findings would inform decision-making of practitioners, policy makers, and law-enforcement officials in terms of focus of attention and allocation of anti-counterfeiting resources. Although it sounds controversial, the findings of this research imply that anti-counterfeiting effort focusing on reducing availability of counterfeits might not lead to fruitful anti-counterfeiting outcomes as one would expect.

As assuring as they are, the findings of this research needs to be read with caution given the research was conducted in China, which is the hub of counterfeits where buying and using counterfeits are socially acceptable (Cheung and Prendergast 2006). In addition, China is a place where consumers crave luxury brands and purchase originals and counterfeits for different usage situations (Bian et al. 2016). Based on these considerations, the practical implications of this finding are very likely to be context specific.

\section{Limitations and future research directions}

As with many other studies this research is not without limitations. For example, the current research has measured one outcome variable, patronage of originals and counterfeits, 
which mainly captured consumers' interest and purchase tendency. As much contribution as this research brings to both brand management and counterfeit literature, it is unclear whether the findings of this research would hold true for more downstream variables, for example actual behavior, post-purchase evaluation, and word-of-mouth. Testing the conceptual framework with more downstream variables is a viable direction for future research.

Although the sample size of this research is statistically adequate, it is relatively small and is treated as unidimensional. Future research could replicate this research using a larger sample size in different research contexts, for example distinct geographic locations. This research only captured data concerning luxury brands; thus, findings might not necessarily be applicable to generic brands, which are also heavily counterfeited. Further research in this direction is needed. With a larger sample size, future research could also take into consideration of diversified motivations of counterfeit consumption purchase. Last (but not least), despite the commonly shared concern that consumer past experience would mitigate marketing effort of originals, our data suggest otherwise. Specifically, moderation effect of both past original experience and counterfeit experience does not exist. This finding, although supported by empirical data, is surprising and should be viewed with caution. Future research needs to validate this finding using data from different contexts, for example the USA and UK, where counterfeits are also widely accessible and regularly purchased.

\section{Compliance with ethical standards}

Conflict of interest On behalf of all authors, the corresponding author states that there is no conflict of interest.

Open Access This article is licensed under a Creative Commons Attribution 4.0 International License, which permits use, sharing, adaptation, distribution and reproduction in any medium or format, as long as you give appropriate credit to the original author(s) and the source, provide a link to the Creative Commons licence, and indicate if changes were made. The images or other third party material in this article are included in the article's Creative Commons licence, unless indicated otherwise in a credit line to the material. If material is not included in the article's Creative Commons licence and your intended use is not permitted by statutory regulation or exceeds the permitted use, you will need to obtain permission directly from the copyright holder. To view a copy of this licence, visit http://creativecommons.org/licenses/by/4.0/.
Appendix 1: Respondents' profile

\begin{tabular}{|c|c|c|c|c|}
\hline Variable & Total samples & Categories & $n$ & Percentage \\
\hline \multirow[t]{2}{*}{ Gender } & \multirow[t]{2}{*}{266} & Female & 116 & 43.6 \\
\hline & & Male & 150 & 56.4 \\
\hline \multirow[t]{6}{*}{ Age } & \multirow[t]{6}{*}{266} & $<18$ & 0 & 0.0 \\
\hline & & $18-24$ & 85 & 32.00 \\
\hline & & $25-34$ & 75 & 28.2 \\
\hline & & $35-44$ & 73 & 27.4 \\
\hline & & $45-54$ & 33 & 12.4 \\
\hline & & $>54$ & 0 & 0.0 \\
\hline \multirow[t]{4}{*}{$\begin{array}{l}\text { Educational } \\
\text { level }\end{array}$} & \multirow[t]{4}{*}{266} & $\begin{array}{l}\text { Primary educa- } \\
\text { tion }\end{array}$ & 5 & 1.9 \\
\hline & & $\begin{array}{l}\text { Secondary } \\
\text { education } \\
\text { (high school) } \\
\text { or technical } \\
\text { education) }\end{array}$ & 49 & 18.4 \\
\hline & & $\begin{array}{l}\text { University } \\
\text { education } \\
\text { (university) }\end{array}$ & 81 & 30.5 \\
\hline & & $\begin{array}{l}\text { Postgraduate } \\
\text { degree or } \\
\text { higher }\end{array}$ & 131 & 49.2 \\
\hline \multirow{6}{*}{$\begin{array}{l}\text { Monthly house- } \\
\text { hold income }\end{array}$} & \multirow[t]{6}{*}{266} & $<10,000$ RMB $¥$ & 1 & 0.4 \\
\hline & & $\begin{array}{l}\text { 10,000-49,999 } \\
\text { RMB¥ }\end{array}$ & 125 & 47 \\
\hline & & $\begin{array}{l}\text { 50,000-99,999 } \\
\text { RMB¥ }\end{array}$ & 102 & 38.3 \\
\hline & & $\begin{array}{c}100,000- \\
149,999 \\
\text { RMB¥ }\end{array}$ & 22 & 8.3 \\
\hline & & $\begin{array}{c}150,000- \\
199,999 \\
\text { RMB¥ }\end{array}$ & 6 & 2.2 \\
\hline & & $\begin{array}{c}>200,000 \\
\text { RMB¥ }\end{array}$ & 10 & 3.8 \\
\hline
\end{tabular}




\section{Appendix 2: Measures and psychometric properties}

\begin{tabular}{|c|c|c|c|c|c|c|c|c|c|}
\hline \multirow{2}{*}{$\begin{array}{l}\text { Constructs and } \\
\text { items } \\
\text { Emotional brand } \\
\text { attachment }\end{array}$} & \multirow[t]{2}{*}{$M$} & \multirow[t]{2}{*}{ SD } & \multirow{2}{*}{$\begin{array}{l}\text { Cronbach's } \alpha \\
.89\end{array}$} & \multirow{2}{*}{$\begin{array}{l}\text { Cronbach's } \alpha \text { if } \\
\text { item deleted }\end{array}$} & \multicolumn{5}{|c|}{ Correlation } \\
\hline & & & & & 1 & 2 & 3 & 4 & 5 \\
\hline Affection & 5.04 & 1.30 & & .87 & & & & & \\
\hline Love & 4.88 & 1.35 & & .88 & $.54 * *$ & & & & \\
\hline Connection & 4.59 & 1.29 & & .87 & $.48 * *$ & $.65 * *$ & & & \\
\hline Passion & 4.96 & 1.37 & & .86 & $.62 * *$ & $.52 * *$ & $.64 * *$ & & \\
\hline Delight & 5.54 & 1.31 & & .87 & $.54 * *$ & $.60 * *$ & $.57 * *$ & $.64 * *$ & \\
\hline Captivation & 5.04 & 1.51 & & .87 & $.63 * *$ & $.50 * *$ & $.49 * *$ & $.65^{* *}$ & $.58 * *$ \\
\hline \multicolumn{10}{|c|}{ Brand involvement } \\
\hline Importance & 4.49 & 1.23 & & & & & & & \\
\hline Relevance & 4.53 & 1.20 & & & $.81 * *$ & & & & \\
\hline \multicolumn{10}{|c|}{ Original patronage } \\
\hline Intention & 5.27 & 1.32 & & & & & & & \\
\hline Interest & 5.16 & 1.28 & & & $.86^{* *}$ & & & & \\
\hline \multicolumn{10}{|c|}{ Counterfeit patronage } \\
\hline Intention & 3.76 & 1.37 & & & & & & & \\
\hline Interest & 3.74 & 1.38 & & & $.89 * *$ & & & & \\
\hline \multicolumn{10}{|c|}{ Original experience } \\
\hline Regularity & 2.91 & 1.36 & & & & & & & \\
\hline Ownership & 6.09 & 8.12 & & & $.48 * *$ & & & & \\
\hline \multicolumn{10}{|c|}{ Counterfeit experience } \\
\hline Regularity & 2.35 & 1.50 & & & & & & & \\
\hline Ownership & 4.79 & 6.70 & & & $.63^{* *}$ & & & & \\
\hline
\end{tabular}

$* * p \leq .01$

\section{References}

Ainsworth, M.D.S., M.C. Blehar, E. Waters, and S.N. Wall. 1978. Patterns of attachment: a psychological study of the strange situation. Hillsdale, NJ: Lawrence Erlbaum Associates Inc.

Alonso-Dos-Santos, M., O. Llanos-Contreras, and P. Farías. 2019. Family firms' identity communication and consumers' product involvement impact on consumer response. Psychology \& Marketing 36(8): 791-798.

Antonopoulos, G.A., and A. Hall. 2018. Fake goods, real money: The counterfeiting business and its financial management. Bristol: Policy Press.

Antonopoulos, G.A., A. Hall, J. Large, and A. Shen. 2017. An introduction to the special issue on 'counterfeiting'. Trends in Organized Crime 20(3): 247-251.

Bagozzi, R.P. 1981. Attitudes, intentions, and behavior: A test of some key hypotheses. Journal of Personality and Social Psychology 41(4): 607-627.

Bamberg, S., I. Ajzen, and P. Schmidt. 2003. Choice of travel mode in the theory of planned behavior: The roles of past behavior, habit, and reasoned action. Basic and Applied Social Psychology 25(3): 175-187.

Belk, R.W. 1988. Possessions and the extended self. Journal of Consumer Research 15(2): 139-168.

Bian, X. 2006. An examination of factors influencing the formation of the consideration set and consumer purchase intention in the context of non-deceptive counterfeiting. PhD Thesis, University of Glasgow.

Bian, X. 2018. Do counterfeits only affect brands that are heavily counterfeited? New insights. The Brand Protection Professional 3 (2): $20-22$.

Bian, X., and L. Moutinho. 2011. The role of brand image, product involvement, and knowledge in explaining consumer purchase behaviour of counterfeits: Direct and indirect effects. European Journal of Marketing 45(1/2): 191-216.

Bian, X., and C. Veloutsou. 2007. Consumers' attitudes regarding nondeceptive counterfeit brands in the UK and China. Journal of Brand Management 14(3): 211-222.

Bian, X., K.Y. Wang, A. Smith, and N. Yannopoulou. 2016. New insights into unethical counterfeit consumption. Journal of Business Research 69 (10): 4249-4258.

Bloch, P.H. 1982. Involvement beyond the purchase process: Conceptual issues and empirical investigation. Advances in Consumer Research 9: 413-417.

Bloch, P.H., and M.L. Richins. 1983. A theoretical model for the study of product importance perceptions. Journal of Marketing 47(3): 69-81.

Bowlby, J. 1979. The making and breaking of affectional bonds. London: Tavistock Publications.

Bowlby, J. 1980. Attachment and loss. New York: Basic Books.

Cailleux, H., C. Mignot, and J.N. Kapferer. 2009. Is CRM for luxury brands? Journal of Brand Management 16(5-6): 406-412. 
Chakravarti, A., and C. Janiszewski. 2003. The influence of macrolevel motives on consideration set composition in novel purchase situations. Journal of Consumer Research 30(2): 244-258.

Chaudhry, P., and M.G. Walsh. 1996. An assessment of the impact of counterfeiting in international markets: The piracy paradox persists. The Columbia Journal of World Business 31(3): 34-48.

Cheah, I., I. Phau, C. Chong, and A.S. Shimul. 2015. Antecedents and outcomes of brand prominence on willingness to buy luxury brands. Journal of Fashion Marketing and Management 19(4): 402-415.

Cheung, W.L., and G. Prendergast. 2006. Buyers' perceptions of pirated products in China. Marketing Intelligence \& Planning 24(5): 446-462.

Churchill, G.A., and D. Iacobucci. 1999. Marketing research: Methodological foundations. Fort Worth, TX: Dryden Press.

Cumming, G. 2009. Inference by eye: Reading the overlap of independent confidence intervals. Statistics in Medicine 28(2): 205-220.

Darmon, R., and M. Laroche. 1991. Advertising in Canada-A managerial approach. Ryerson, Toronto: McGraw-Hill.

de Matos, A.C., C.T. Ituassu, and C. Rossi. 2007. Consumer attitudes toward counterfeits: A review and extension. Journal of Consumer Marketing 24(1): 36-47.

Dunn, L., and J. Hoegg. 2014. The impact of fear on emotional brand attachment. Journal of Consumer Research 41(1): 152-168.

Eisend, M., P. Hartmann, and V. Apaolaza. 2017. Who buys counterfeit luxury brands? A meta-analytic synthesis of consumers in developing and developed markets. Journal of International Marketing 25(4): 89-111.

Eisend, M., and P. Schuchert-Güler. 2006. Explaining counterfeit purchases: A review and preview. Academy of Marketing Science Review 2006(1): 1-25.

Evans, B.P., R.G. Starr, and R.J. Brodie. 2019. Counterfeiting: Conceptual issues and implications for branding. Journal of Product \& Brand Management 28(6): 707-719.

Fastoso, F., and H. González-Jiménez. 2018. Materialism, cosmopolitanism, and emotional brand attachment: The roles of ideal self-congruity and perceived brand globalness. Journal of Business Research. https://doi.org/10.1016/j.jbusres.2018.12.015.

Feng, R., W. Ma, R. Liu, M. Zhang, Z. Zheng, T. Qing, J. Xi, X. Lai, and C. Qian. 2019. How preferred brands relate to the self: The effect of brand preference, product involvement, and information valence on brand-related memory. Frontiers in Psychology 10: 783. https://doi.org/10.3389/fpsyg.2019.00783.

Fill, C. 2005. Marketing communications: Engagements, strategies and practice. London: Pearson Education.

Fournier, S. 1998. Consumers and their brands: Developing relationship theory in consumer research. Journal of Consumer Research 24(4): 343-373.

Friedmann, E., and O. Lowengart. 2019. Gender segmentation to increase brand preference? The role of product involvement. Journal of Product \& Brand Management 28(3): 408-420.

Gentry, J.W., S. Putrevu, C. Shultz, and S. Commuri. 2001. How now Ralph Lauren? The separation of brand and product in a counterfeit culture. Advances in Consumer Research 28: 258-265.

Grewal, D., K.B. Monroe, and R. Krishnan. 1998. The effects of price-comparison advertising on buyers' perceptions of acquisition value, transaction value, and behavioral intentions. Journal of Marketing 62(2): 46-59.

Hazan, C., and D. Zeifman. 1999. Pair bonds as attachments. In Handbook of attachment: Theory, research, and clinical applications, ed. J. Cassidy and P.R. Shaver, 336-354. New York: The Guilford Press.

Hill, N., and J. Alexander. 2006. The handbook of customer satisfaction and loyalty measurement. UK: Gower Publishing.
Hung, H.Y., and H.T. Lu. 2018. The rosy side and the blue side of emotional brand attachment. Journal of Consumer Behaviour 17(3): 302-312.

International Anti Counterfeiting Coalition. 2011. Counterfeiting adds up. https://www.iacc.org/resources/about/statistics. Accessed 18 Dec 2018.

International Chamber of Commerce. 2011. Estimating the global economic and social impacts of counterfeiting and piracy. https://cdn.iccwbo.org/content/uploads/sites/3/2016/11/ICCBASCAP-Global-Impacts-Full-Report-2011.pdf. Accessed 18 Dec 2018.

Japutra, A., Y. Ekinci, and L. Simkin. 2014. Exploring brand attachment, its determinants and outcomes. Journal of Strategic Marketing 22(7): 1-15.

Japutra, A., Y. Ekinci, L. Simkin, and B. Nguyen. 2018. The role of ideal self-congruence and brand attachment in consumers' negative behaviour: compulsive buying and external trash-talking. European Journal of Marketing 52(3/4): 683-701.

Jin, S.A.A. 2012. The potential of social media for luxury brand management. Marketing Intelligence \& Planning 30(7): 687-699.

Johnson, D.J., and C.E. Rusbult. 1989. Resisting temptation: Devaluation of alternative partners as a means of maintaining commitment in close relationships. Journal of Personality and Social Psychology 57(6): 967-980.

Kapferer, J.N., and G. Laurent. 1985. Measuring consumer involvement profiles. Journal of Marketing Research 22(1): 41-53.

Kaufmann, H.R., D.A. Petrovici, C.G. Filho, and A. Ayres. 2016. Identifying moderators of brand attachement for driving customer purchase intention of original vs counterfeits of luxury brands. Journal of Business Research 69(12): 5735-5747.

Kirmani, A., S. Sood, and S. Bridges. 1999. The ownership effect in consumer responses to brand line stretches. Journal of Marketing 63(1): 88-101.

Kleine, R.E., S.S. Kleine, and J.B. Kernan. 1993. Mundane consumption and the self: A social-identity perspective. Journal of Consumer Psychology 2(3): 209-235.

Kleiser, S.B., and J.A. Wagner. 1999. Understanding the pioneering advantage from the decision maker's perspective: The case of product involvement and the status quo bias. Advances in Consumer Research 26: 593-597.

Kokkinaki, F. 1999. Predicting product purchase and usage: The role of perceived control, past behavior and product involvement. Advances in Consumer Research 26: 576-583.

Laaksonen, P. 1994. Consumer involvement: Concepts and research. London: Routledge.

Leckie, C., M.W. Nyadzayo, and L.W. Johnson. 2016. Antecedents of consumer brand engagement and brand loyalty. Journal of Marketing Management 32(5-6): 558-578.

Lianto, V.T. 2015. The impact of past behavior, attitude towards counterfeit, self characteristic, and purchase intention of original crocs towards consumer purchase intention of counterfeit crocs. iBuss Management 3(2): 119-130.

Lin, Y.J. 2011. Fake stuff: China and the rise of counterfeit goods. London: Routledge.

MacInnis, D.J., and C.W. Park. 1991. The differential role of characteristics of music on high-and low-involvement consumers' processing of ads. Journal of Consumer Research 18(2): 161-173.

Malär, L., H. Krohmer, W.D. Hoyer, and B. Nyffenegger. 2011. Emotional brand attachment and brand personality: The relative importance of the actual and the ideal self. Journal of Marketing 75(4): 35-52.

Marticotte, F., and M. Arcand. 2017. Schadenfreude, attitude and the purchase intentions of a counterfeit luxury brand. Journal of Business Research 77: 175-183.

Miller, B.D. 1997. The endangered sex: Neglect of female children in rural North India. India: Oxford University Press. 
Mittal, B., and M.S. Lee. 1988. Separating brand-choice involvement from product involvement via consumer involvement profiles. Advances in Consumer Research 15: 43-49.

Mittal, B., and M.S. Lee. 1989. A causal model of consumer involvement. Journal of Economic Psychology 10(3): 363-389.

Moon, M.A., B. Javaid, M. Kiran, H. Awan, and A. Farooq. 2018. Consumer perceptions of counterfeit clothing and apparel products attributes. Marketing Intelligence \& Planning 36(7): 794-808.

Nia, A., and J.L. Zaichkowsky. 2000. Do counterfeits devalue the ownership of luxury brands? Journal of Product \& Brand Management 9(7): 485-497.

OECD. 2017. Trade in counterfeit products and the UK economy: Fake goods, real losses, illicit trade. Paris: OECD Publishing.

OECD, and EUIPO. 2019. Trends in trade in counterfeit and pirated goods. Paris: OECD Publishing.

Organisation for Co-operation and Economic Development. 2016. Global trade in fake goods worth nearly half a trillion dollars a year - OECD \& EUIPO. http://www.oecd.org/industry/globa 1-trade-in-fake-goods-worth-nearly-half-a-trillion-dollars-ayear.htm. Accessed 16 Dec 2018.

Ouellette, J.A., and W. Wood. 1998. Habit and intention in everyday life: The multiple processes by which past behavior predicts future behavior. Psychological Bulletin 124(1): 54-74.

Park, C.W., D.J. MacInnis, J. Priester, A.B. Eisingerich, and D. Iacobucci. 2010. Brand attachment and brand attitude strength: Conceptual and empirical differentiation of two critical brand equity drivers. Journal of Marketing 74(6): 1-17.

Park, C.W., and B. Mittal. 1985. A theory of involvement in consumer behavior: Problems and issues. In Research in consumer behavior, ed. Jagdish N. Sheth, 201-231. Greenwich: Jai Press Inc.

Penz, E., and B. Stöttinger. 2008. Original brands and counterfeit brands-Do they have anything in common? Journal of Consumer Behaviour: An International Research Review 7(2): 146-163.

Petty, R.E., and J.T. Cacioppo. 1986. The elaboration likelihood model of persuasion. In Advances in Experimental Social Psychology, ed. Leonard Berkowitz, 123-205. New York: Academic Press.

Phau, I., and M. Teah. 2009. Devil wears(counterfeit) Prada: A study of antecedents and outcomes of attitudes towards counterfeits of luxury brands. Journal of Consumer Marketing 26(1): 15-27.

Rothschild, M.L., and M.J. Houston. 1980. Individual differences in voting behavior: Further investigations of involvement. Advances in Consumer Research 7: 655-658.

Schneider, W., and R.M. Shiffrin. 1977. Controlled and automatic human information processing: I. Detection, search, and attention. Psychological Review 84(1): 1-66.

Schouten, J.W., and J.H. McAlexander. 1995. Subcultures of consumption: An ethnography of the new bikers. Journal of Consumer Research 22(1): 43-61.

Seetharaman, P.B., A. Ainslie, and P.K. Chintagunta. 1999. Investigating household state dependence effects across categories. Journal of Marketing Research 36(4): 488-500.

Shimul, A.S., I. Phau, and M. Lwin. 2019. Conceptualising luxury brand attachment: Scale development and validation. Journal of Brand Management 1: 2-8. https://doi.org/10.1057/s41262-01900158-6.

Solomon, M.R., C. Surprenant, J.A. Czepiel, and E.G. Gutman. 1985. A role theory perspective on dyadic interactions: The service encounter. Journal of Marketing 48(1): 99-111.

Stewart, K., M. Kammer-Kerwick, A. Auchter, H. Koh, M. Dunn, and I. Cunningham. 2019. Examining digital video advertising (DVA) effectiveness. European Journal of Marketing 53(11): 2451-2479.

Swike, E., S. Thompson, and C. Vasquez. 2008. Piracy in China. Business Horizons 51(6): 493-500.
Theng, S.J., A.G. Parsons, and S.F. Yap. 2013. Corporate branding, emotional attachment and brand loyalty: The case of luxury fashion branding. Journal of Fashion Marketing and Management 17(4): 403-423.

Thomson, M., D.J. Macinnis, and C.W. Park. 2005. The ties that bind: Measuring the strength of consumers' emotional attachments to brands. Journal of Consumer Psychology 15(1): 77-91.

Trijp, H.V., W.D. Hoyer, and J.J. Inman. 1996. Why switch? Product category-level explanations for true variety-seeking behavior. Journal of Marketing Research 33(3): 281-292.

Veloutsou, C., and X. Bian. 2008. A cross-national examination of consumer perceived risk in the context of non-deceptive counterfeit brands. Journal of Consumer Behaviour: An International Research Review 7(1): 3-20.

Vigneron, F., and L.W. Johnson. 2004. Measuring perceptions of brand luxury. Journal of Brand Management 11(6): 484-506.

Wilcox, K., H.M. Kim, and S. Sen. 2009. Why do consumers buy counterfeit luxury brands? Journal of Marketing Research 46: 247-259.

Wilhelmy, A., M. Kleinmann, C.J. König, K.G. Melchers, and D.M. Truxillo. 2016. How and why do interviewers try to make impressions on applicants? A qualitative study. Journal of Applied Psychology 101(3): 313.

Wilson, J.M. 2017. The future of brand protection: Responding to the global risk. Journal of Brand Management 24(3): 271-283.

Wilson, J.M., C. Grammich, and F. Chan. 2016. Organizing for brand protection and responding to product counterfeit risk: An analysis of global firms. Journal of Brand Management 23(3): 345-361.

Wu, G.J., P.R. Bagozzi, A.N. Anaza, and Z. Yang. 2019. A goaldirected interactionist perspective of counterfeit consumption: The role of perceived detection probability. European Journal of Marketing 53(7): 1311-1332.

Yoo, B., and S.H. Lee. 2009. Buy genuine luxury fashion products or counterfeits? Advances in Consumer Research 36: 280-286.

Yoo, B., and S.H. Lee. 2012. Asymmetrical effects of past experiences with genuine fashion luxury brands and their counterfeits on purchase intention of each. Journal of Business Research 65(10): 1507-1515.

Zaichkowsky, J.L. 1985. Measuring the involvement construct. Journal of Consumer Research 12: 341-352.

Zaichkowsky, J.L. 1986. Conceptualizing involvement. Journal of Advertising 15(2): 4-34.

Zhao, X., Z. Niu, and W. Chen. 2013. Interest before liking: Twostep recommendation approaches. Knowledge-Based Systems 48: 46-56.

Publisher's Note Springer Nature remains neutral with regard to jurisdictional claims in published maps and institutional affiliations.

Dr. Xuemei Bian is a Professor in Marketing at Newcastle Business School, University of Northumbria, UK. Her research interests are in consumer behavior, branding and advertising, with a focus on how judgments, evaluations and choice vary as a function of different decision-making strategies. She has published in many journals of international repute, such as Journal of Business Research, European Journal of Marketing, British Journal of Social Psychology, Journal of Consumer Behavior, and Advances in Consumer Research among others.

Sadia Haque is currently a Doctoral Researcher at Newcastle Business School, University of Northumbria, UK. Her research interest lies in consumer behavior, advertising, and counterfeited luxury branded products. 